УДК 551.4.01/02

DOI: 10.32686/1812-5220-2018-15-18-35

ISSN 1812-5220

( П Проблемы анализа риска, 2018

\section{С.Б. Кузьмин,}

Институт географии им. В.Б. Сочавы СО РАН,

г.Иркутск

\section{Районирование Байкальского} региона по опасным геоморфологическим процессам для стратегического планирования в Российской Федерации и Республике Монголия

\begin{abstract}
Аннотация
Эколого-геоморфологическое районирование Байкальского региона по опасным геоморфологическим процессам проведено на основе авторского метода. Байкальский регион включает субъекты Российской Федерации в Южной Сибири и отдельные районы Республики Монголия в границах бассейна оз. Байкал. В основу районирования положены: 1) закономерности пространственного распределения форм рельефа и геоморфологических процессов, оказывающих негативное влияние на экономику и социальную сферу; 2) территориальная организация хозяйства субъектов Российской Федерации и Республики Монголия, а также системы региональных, внутригосударственных и межгосударственных территориально-производственных связей; 3) перспективы социально-экономического развития регионов Южной Сибири, Российской Федерации и Республики Монголия, а также опасные геоморфологические процессы, которые в результате этого могут активизироваться или вновь возникнуть. Исследования направлены на совершенствование государственной системы борьбы с чрезвычайными ситуациями природного и природно-техногенного характера, оптимизацию межгосударственных контактов в области модернизации и разработки новых методов профилактики и прогноза стихийных бедствий и катастроф.
\end{abstract}

Ключевые слова: Байкальский регион, опасные геоморфологические процессы, эколого-геоморфологическое районирование. 


\section{Zoning of Baikal region according to the hazardous geomorphological processes for strategy planning in Russian Federation and Republic of Mongolia}

\section{S.B. Kuzmin,} Institute of Geography mem. V.B. Sotchava SB RAS, Irkutsk

\begin{abstract}
Annotation
Ecological-geomorphological zoning analysis of Baikal Region to hazardous geomorphological processes was carried out on the basis of the author's technique. Baikal Region includes the subjects of the Russian Federation in the South Siberia and Republic of Mongolia within the boundaries of the Lake Baikal Basin. The basis of zoning are: 1) the spatial distribution patterns of dominant landforms and geomorphological processes that have a negative impact on the economy and social sphere; 2) territorial organization of the economy of the Russian Federation and the Republic of Mongolia, as well as regional system of intra and inter regional industrial relations; 3) the prospects for socio-economic development of South Siberia in Russian Federation and the Republic of Mongolia, as well as hazardous geomorphological processes that can be activated or re-emerge in the result. Research aimed at improving the state system to deal with emergency situations of natural and man-made disasters in Russia, optimization of international contacts in the field of modernization and development of new methods of prevention and prediction of natural disasters and catastrophes.
\end{abstract}

Keywords: Baikal Region, geomorphological disasters, ecological-geomorphological zoning.

\section{Содержание}

Введение

1. Принципы и методы исследований

2. Результаты исследований

Заключение

Литература 


\section{Введение}

Байкальский регион (БР) на протяжении многих лет являлся и сегодня является объектом стратегического планирования в СССР, позднее - в Российской Федерации (РФ) и Республике Монголия (РM). В его состав в настоящий момент входят три субъекта РФ - Иркутская область, Республика Бурятия и Забайкальский край, и, кроме того, территория РМ в пределах водосборного бассейна оз. Байкал по границам аймаков.

РФ и РМ в своем трансграничном сотрудничестве руководствуются международными соглашениями. Оба государства подписали Конвенцию о биологическом разнообразии, РМ ратифицировала ее в 1993 г., РФ — в 1995 г. В 1996 г. оз. Байкал получило статус объекта Всемирного природного наследия, а ландшафты долины р. Орхон в РМ в 2000 г. В соответствии с Конвенцией об охране всемирного культурного и природного наследия оба государства подтвердили, что эти ценности принадлежат всему человечеству, а для их сохранения обязаны взаимодействовать все заинтересованные страны.

Сотрудничество по вопросам экологической безопасности и охраны окружающей среды между РМ и РФ (ранее - СССР) началось с подписания в 1974 г. Соглашения о рациональном использовании и охране вод бассейна р. Селенга. В 1988 г. было подписано Соглашение о сотрудничестве в области водного хозяйства на пограничных водах. В 1995 г. страны подписали двустороннее Соглашение по охране и использованию трансграничных вод, которое заменило два предшествующих и является сегодня главным правоустанавливающим документом в трансграничном экологическом сотрудничестве РФ и РМ.

В 2002 г. Правительство РФ учредило Федеральное агентство по охране окружающей среды оз. Байкал (с 2012 г. - Территориальный отдел водных ресурсов по РФ Енисейского бассейнового водного управления), в сферу деятельности которого входит координирование межгосударственного взаимодействия с РМ по вопросам экологической безопасности.

В 2006 г. создана совместная рабочая группа по трансграничному управлению бассейном оз. Байкал под председательством руководителей ве- домств по водным ресурсам обеих стран. В качестве пилотного проекта был предложен бассейн р. Селенга.

В 2007 г. Государственной Думой РФ учреждена Межведомственная комиссия по сохранению оз. Байкал, в состав которой вошли представители Минприроды России, Росприроднадзора, Иркутской области, Республики Бурятия, Забайкальского края, шести федеральных министерств, Российской академии наук. Цель Комиссии состояла в разработке и координации выполнения государственной политики в области охраны оз. Байкал. В задачи комиссии входило уточнение и закрепление нормативно-правовых актов в области охраны окружающей среды и рационального использования природных ресурсов в пределах Байкальской природной территории (БПТ), мониторинг состояния экосистем и ландшафтов, выполнение обязательств по защите оз. Байкал и всего БР.

В 2008 г. был составлен перечень загрязняющих веществ, сбросы которых должны контролироваться обеими странами. Заключено Соглашение о двусторонней оценке трансграничных районов р. Селенга и ее притоков, риска здоровью человека, целостности и функциональности хозяйственной инфраструктуры РФ и РМ. Страны проводят гидрологический и гидрохимический мониторинг, но национальные протоколы данных до сих пор разрознены.

В 2011 г. прошла встреча делегаций РФ и РМ в рамках Соглашения по охране и использованию трансграничных водотоков, в ходе которой был подписан окончательный Протокол о двустороннем сотрудничестве. Совместная рабочая группа обсудила вопросы, связанные с регулярным обменом информацией, сотрудничеством по реализации Соглашения и согласованием методов мониторинга между двумя странами, а также список контролируемых загрязняющих веществ и стандартов качества окружающей среды.

В 2012 г. вышло Постановление Правительства РФ от 21.08.2012 № 8 «Программа развития Байкальской природной территории на 2012 2020 годы». Ее цель: охрана оз. Байкал и защита БПТ от негативного воздействия антропогенных, техногенных и природных факторов. Задачи определены следующие: 1) сокращение сбросов 
загрязняющих веществ в водные объекты БПТ; 2) снижение уровня загрязненности отходами, в т.ч. обеспечение восстановления территорий, подвергшихся высокому загрязнению; 3) повышение эффективности использования рекреационного потенциала особо охраняемых природных территорий (ООПТ); 4) сохранение и воспроизводство биологических и других природных ресурсов; 5) развитие государственного экологического мониторинга уникальной экологической системы оз. Байкал; 6) развитие системы защиты берегов оз. Байкал, рек и иных водоемов БПТ.

В 2014 г. вступил в силу Федеральный закон от 28.06.2014 № 181 «О внесении изменений в отдельные законодательные акты РФ», который ужесточил режим использования земель на БПТ. Согласно закону БПТ - это территория, в состав которой входят оз. Байкал, водоохранная зона, водосборная площадь, прилегающие особо охраняемые природные территории, а также территория шириной 200 км на запад и северо-запад от озера. Новый закон о Байкале накладывает ограничения на использование земельных участков. Основным изменением является запрет на строительство новых хозяйственных объектов, реконструкцию действующих хозяйственных объектов без положительного заключения государственной экологической экспертизы проектной документации таких объектов.

В 2017 г. Правительство РФ издало Постановление от 30 марта 2017 г. № 365 «О внесении изменений в государственную программу РФ “Социально-экономическое развитие Дальнего Востока и Байкальского региона"». Нам интересна подпрограмма 3 «Поддержка реализации инвестиционных проектов в Байкальском регионе». Цель подпрограммы: создание современных конкурентоспособных производств в субъектах РФ, расположенных в Байкальском регионе. Задачи: 1) создание и модернизация объектов транспортной, инженерной, энергетической и (или) социальной инфраструктуры для обеспечения реализации инвестиционных проектов в БР, отобранных в порядке, установленном Правительством РФ;2) реализация инвестиционных проектов в Байкальском регионе с участием акционерного общества «Фонд развития Дальнего Востока и Байкальского региона».
Основные положения государственной политики по развитию БР отражены в Распоряжении Правительства РФ от 05.07.2010 № 1120-р «Об утверждении Стратегии социально-экономического развития Сибири до 2020 года». Суровые природно-климатические условия Южной Сибири и северной части Монголии обусловливают масштабную активизацию опасных природных процессов при хозяйственном освоении отдельных регионов. Это требует надежных знаний об их закономерностях для предотвращения стратегических просчетов в эколого-экономической политике. Эти функции прописаны в Постановлении Правительства РФ от 15.04.2014 № 300 «О реализации государственной программы МЧС «Защита населения и территорий от чрезвычайных ситуаций» до 2020 г.

29 марта 2017 г. Главное управление МЧС России и Государственное агентство по чрезвычайным ситуациям Монголии подписали план совместных действий по вопросам предупреждения и ликвидации чрезвычайных ситуаций на 2017 г. Такая практика применяется уже более десяти лет, а вопросы международного сотрудничества приобретают все большее значение в современных условиях, способствуя консолидации усилий двух государств в деле предупреждения и защиты населения и территорий обеих стран от ЧС.

4 августа 2017 г. в поселке Танхой Республики Бурятия прошло совещание по вопросам экологического развития БПТ под председательством Президента РФ В.В. Путина. Он поручил определить источники финансирования для полной ликвидации накопленного экологического ущерба на Байкале. По словам Президента, первоочередными являются следующие меры: ликвидировать экологический ущерб, провести полноценную рекультивацию загрязненных территорий, разобраться и с объектами, продолжающими работать, очистные сооружения большинства из которых изношены, разрабатывать варианты софинансирования экологоориентированных проектов, при этом с особым вниманием нужно относиться к обеспечению систем жесткого контроля. Байкал является достоянием не только России, но и всей планеты, сбережение озера является государственным приоритетом РФ. 
Тем не менее на местах, в регионах ситуация с защитой окружающей среды и экологической безопасностью на БПТ меняется очень медленно. Анализ правового регулирования этих вопросов на уровне муниципальных образований показывает, что органами местного самоуправления не принимаются специальные нормативные акты, посвященные непосредственно защите БПТ как уникального природного комплекса. Регулирование сводится к принятию нормативных правовых актов общего характера. Его очевидным недостатком является отсутствие координации нормотворчества различных муниципальных образований, недостаток методической помощи со стороны органов государственной власти, отсутствие реальных инструментов воздействия на природопользователей. В развитии нормативной базы на муниципальном уровне скрыт большой потенциал, который должен быть использован как элемент комплексного подхода к обеспечению регулирования вопросов охраны БПТ. Недостаточно используется потенциал научных и научно-исследовательских организаций, в которых проводятся работы по всестороннему изучению опасных природных процессов.

Защита от опасных природных процессов в БР осуществляется территориальными органами МЧС Правительства Российской Федерации и Главного управления по чрезвычайным ситуациям (ГУЧС) Правительства Республики Монголия. Их основные задачи состоят в следующем: 1) peализация государственной политики в области гражданской обороны (ГО), защиты населения и территорий от чрезвычайных ситуаций (ЧС); 2) управление в области ГО, защиты населения и территорий от ЧС; 3 ) надзорные и контрольные функции в области ГО и ЧС; 4) осуществление деятельности по организации и ведению ГО, экстренному реагированию при ЧС, в т.ч. по чрезвычайному гуманитарному реагированию, защите населения и территорий от ЧС и пожаров, обеспечению безопасности людей на водных объектах. Их решение невозможно без полноценного и качественного картографического сопровождения, обеспечивающего пространственную привязку мероприятий в области ГО и ЧС. Большое значение в этом смысле имеют уже разработанные картографические произведения, оценивающие на разных уровнях степень опасности стихийных бедствий и катастроф, основанные на научных рекомендациях и методиках. Их вовлечение в государственную политику предупреждения и ликвидации ЧС представляется актуальным и своевременным.

В этой сложной обстановке большое значение приобретает разработка новых унифицированных методик создания карт геоэкологической направленности, в частности, опасных природных процессов, которые позволили бы сопоставлять угрозы в области природопользования для отдельных отраслей экономики, территорий, округов и субъектов РФ и РМ. Эти тематические и интегральные карты должны служить основой для разработки трансграничных (международных), федеральных и региональных нормативных документов, с учетом которых органы власти обеих стран принимают решения по использованию территорий, по предупреждению и ликвидации ЧС, по управлению риском природопользования.

В связи с этим нами предпринята качественная оценка опасных геоморфологических процессов посредством создания карты эколого-геоморфологического районирования БР. Карта служит основным рекомендательным документом для региональных структур РФ и РМ в процессе ведения ими хозяйственной деятельности на БПТ.

\section{1. Принципы и методы исследований}

Оценка опасных для населения и хозяйства природных процессов на определенной территории проводится на основе ее геоэкологического районирования под конкретный аспект исследований, для определенных практических целей и задач. Геоэкологическое районирование территории - это интегрированный подход, который вбирает в себя преобразованные ранее географией и экологией сравнительный, системный и временной подходы на основе гетерогенной целостности природных систем. Традиционные методы географии при этом требуют существенной доработки при исследовании таких сложных объектов, как хозяйственно освоенные природно-территориальные комплексы. Возникает необходимость рационального комплексирования различных методов и подходов 
в зависимости от характера решаемых задач, природных особенностей и хозяйственной специфики регионов: моделирование, районирование, системный анализ и др. Районирование в этом случае выступает в качестве основы для поиска оптимального режима функционирования природных и техногенных систем, для уменьшения риска вызвать в них необратимые негативные изменения.

В границах БР широкое развитие получили масштабные активные современные и позднекайнозойские геолого-геоморфологические геодинамические процессы, формирующие основной морфологический облик территории. При ее хозяйственном освоении эти процессы активно воздействуют на производственную инфраструктуру и человека, создавая конкретные угрозы и обусловливая риск природопользования, для снижения которого приходится проводить как специальные защитные мероприятия превентивного характера, так и дорогостоящие восстановительные и реабилитационные работы. Эти задачи решают территориальные органы МЧС РФ и ГУЧС РМ в рамках законодательства этих стран.

В настоящее время в отечественной литературе накоплен достаточный опыт по геоэкологическому районированию крупных территорий хозяйственного освоения $[1,2,8,10,15,18,19,22$ и др.]. В Институте географии РАН разработаны оригинальные принципы оценки, классификации и картографирования природных и природно-техногенных опасностей для РФ и ее субъектов. Внимание сосредоточено на двух видах ущерба: 1) экологических - жизни и здоровью людей, природному комплексу; 2) социально-экономических - социально-хозяйственной инфраструктуре и ресурсной базе. При оценке вероятности ущерба во внимание принята пороговая устойчивость природных процессов, при которой ущерб становится значимым для данной отрасли хозяйства или субъекта РФ [6, 20]. В МГУ разработаны специальные методы оценки природной опасности и риска, классификации эколого-геоморфологических ситуаций, районирования территорий по опасным природным процессам. На их основе проведено мелкомасштабное районирование РФ по отдельным опасным процессам и по комплексному показателю [17]. Ландшафтно-геоморфологический подход к геоэкологиче- скому районированию территорий хозяйственного освоения используется в конкретных практических разработках в ведущих проектных и научно-производственных институтах: ВСЕГЕИ, ВСЕГИНГЕО, ИМГРЭ и др. Считается, что он наилучшим образом обеспечивает комплексную оценку экологического состояния территории.

Ярким примером такого комплексного подхода с использованием геоморфологических ландшафтов являются карты геоэкологических условий и районирования отдельных территорий в разных масштабах для территории Пермского края, с помощью которых проведены специальный ландшафтно-геоморфологический и комплексный геоэкологический анализ, последующая типизация природных и техногенных ландшафтов, сопровождавшаяся картированием современных ландшафтов по космическим снимкам [9].

В зарубежной литературе также имеются примеры ландшафтно-экологического или геоэкологического подхода к оценке территорий хозяйственного освоения, в т.ч. специализированные методики оценки опасных геоморфологических процессов [24-30].

Одним из видов рассмотренных выше геоэкологических исследований является предлагаемый нами в настоящей статье подход к созданию карт эколого-геоморфологического районирования, на которых выделяются районы с различным уровнем развития и составом опасных геоморфологических процессов, с различной хозяйственной специализацией и вектором социально-экономического развития. Специально и подробно этот вопрос рассмотрен в наших предыдущих работах $[13,14]$. Здесь кратко остановимся на основных моментах, а также обсудим специфику составления карты для БР как трансграничной территории.

Эколого-геоморфологическое районирование БР базируется на принципах общего геоэкологического районирования, но учитывает специфический отклик рельефа на антропогенное воздействие, прямые и обратные связи в природно-антропогенных системах, их трансформацию. Эколого-геоморфологические районы - это многокритериальные системы. Они образуют комплекс многоцелевого разноуровневого районирования, которое включает природные, 
природно-ресурсные и хозяйственные уровни системной организации рельефа. Это вызывает трудности в проведении границ между районами. Однозначного решения этого вопроса нет, т.к. случаи совмещения природных и хозяйственно-административных или государственных границ - скорее исключение, чем правило. Поэтому в качестве рубежей высокого ранга принимаются в основном границы субъектов РФ и РМ, а внутренние границы районов более низкого ранга проводятся с учетом особенностей структуры рельефа.

Главными методологическими принципами проведенного нами районирования являются: 1) принцип пространственно-временной неоднородности, связанный с последовательной сменой по площади типов природной среды; 2) принции цели, определяющий объем и содержание собираемой, анализируемой и обобщаемой информации, отображающейся на картах эколого-геоморфологического районирования; 3) принцип систематики элементов районирования, позволяющий представить множество эколого-геоморфологических объектов в упорядоченной и удобной для практического использования форме. Используются базовые методические подходы географии и геоэкологии: 1) историко-динамический, который позволяет оценить современное состояние природной среды в связи с ее функционированием, динамикой и эволюцией, а также обратимые и необратимые смены ее инвариантов во времени; 2) генетическиц̆, который позволяет оценить экологическую обстановку в регионе на основе отклика природной среды на различные виды человеческой деятельности; 3) эколого-географический, который позволяет установить взаимосвязи человека с окружающей средой с учетом последствий их взаимодействия, приводящих к формированию территориально организованных, развивающихся в пространстве и времени географических систем; 4) структурно-географический, который позволяет рассматривать природные, технические и природно-технические системы в функционально-пространственном сопряжении, когда они связаны между собой специфическими потоками энергии, вещества и информации.

В основе визуализации результатов эколого-геоморфологического районирования БР лежит картографический принцип совмещения контуров рай- онов, определяемых геоморфологическими и хозяйственными условиями, степенью вовлечения ландшафтов в хозяйственное использование, однотипностью факторов антропогенного воздействия на рельеф.

Анализ объектов эколого-геоморфологического районирования БР с целью обеспечения защиты хозяйства и человека от опасных геоморфологических процессов и явлений поставил перед нами следующие задачи: 1) выбор адекватного исходного описания объектов районирования; 2) выбор адекватных методов классификации процессов; 3) содержательный наглядный анализ и интерпретация результатов классификации и картографирования.

Нами использован традиционный способ физико-географического или ландшафтного районирования, который связан с многоаспектной типологизацией объектов и обеспечивает развернутое представление эколого-геоморфологических районов в результате построения мысленно-логических матриц геоморфологических и природно-хозяйственных условий. Эти районы являются неформальными картографическими моделями, а их уровням условно соответствуют нечисловые, вербальные геоморфологические и природно-хозяйственные показатели, которые не обязаны находиться в иерархической зависимости друг от друга. В дальнейшем выделение эколого-геоморфологических районов осуществляется путем последовательного объединения отдельных элементов разных уровней этих логических матриц или последовательного наложения одномерных группировок или тематических слоев, как это обычно и делается при интегральных эколого-хозяйственных оценках [5]. В дополнение нами использован специальный подход к многомерной классификации объектов, который основан на использовании качественного показателя их сходства или различия по всему комплексу геоморфологических процессов и видов природопользования и применении методов таксономии $[3,4]$. Это позволяет уже в полной мере реализовать принцип комплексности с переходом к обобщению объектов эколого-геоморфологического районирования, легко представить данные в наглядной форме посредством ГИС-технологии.

Под эколого-геоморфологическим районом независимо от его ранга будем в дальнейшем понимать 
такой участок земной поверхности, который относительно однороден по генетической взаимосвязанности разнокачественных геоморфологических условий и обладает относительно устойчивым набором видов природопользования. Это определенный таксон территории, который будет наделен специфическим геоморфологическим и социально-экономическим содержанием. При этом рельеф рассматривается и как среда, видоизмененная в результате хозяйственной деятельности, и как источник ресурсов, плацдарм для развития хозяйства. Такая объективная сложность элементов экологогеоморфологического районирования БР требует для их описания использовать детерминированный, стохастический, нечеткий (размытый) подход. Поэтому в соответствии с принципом дополнительности Бора необходимо в будущем учитывать фактор неполноты и неопределенности исходной информации как объективное ограничивающее условие принятия обоснованных управленческих решений на основе предлагаемого нами районирования БР.

В работе определены три уровня районирования: макрорегион, регион, район. Макрорегионы и регионы выделены на административно-территориальной и морфоструктурной основах. Для районов дополнительно учитывался класс геоморфологических процессов по их генезису. Опасные геоморфологические процессы выделялись по их реально существующему или возможному в ближайшей перспективе (5-10 лет) негативному воздействию на главные виды хозяйственной деятельности в единицах районирования. Критериями по геоморфологическому фактору являлись морфометрия рельефа (высота, расчлененность и т.п.) и преобладающие по площади и интенсивности рельефообразующие процессы. Опасные геоморфологические процессы для БР определены и согласованы по специальным нормативным документам: СНиП 22-01-95 «Геофизика опасных природных воздействий», СП 11-105-97 «Инженерно-геологические изыскания для строительства», СНиП 22-02-2003 «Инженерная защита территорий, зданий и сооружений от опасных геологических процессов», а также на основе нормативных документов МЧС РФ и ГУЧС РМ.

В основе проведенного нами эколого-геоморфологического районирования БР лежит класси- фикация объектов, которая всегда субъективна, т.к. направлена на достижение конкретной цели. Цель при этом не всегда может быть определена достаточно точно, что обуславливает трудность и неоднозначность формализованного представления сходства и различия между объектами районирования. Сами классификации дискретны, т.к. в результате их использования генерируется нечисловая информация, формируются номинальные или ранговые показатели, которые могут иметь определенное конечное число значений наименований классов. Поэтому результат любого районирования в этом случае представляет собой определенный синтетический обобщенный нечисловой показатель, значениями которого являются наименования соответствующих классов объектов $[21,23]$.

В процессе картографирования опасных геоморфологических процессов использованы следующие методические наставления и научные принципы. Принции ранговости требует соблюдения пространственной иерархии при выделении на карте геоморфологических элементов или развитых на них процессов. Принцип полноты деления требует, чтобы вся территория была разделена на объекты в соответствии с выбранной методикой. Принцип целостности требует, чтобы каждый из картографируемых элементов рельефа отвечал определенному этапу рельефообразования, принадлежал к определенному генетическому типу, характеризовался определенными морфометрическими показателями, геоморфологическими процессами и структурно-вещественными комплексами. Принцип однородности описания требует, чтобы каждый типологический элемент был охарактеризован одинаковым набором свойств с равной степенью детальности в соответствии с уровнем принятой систематики. Принизи специализации требует использовать такое разбиение элементов рельефа, которое наиболее полно отвечает поставленным целям и задачам. Принции однородности грании требует проведения границ между геоморфологическими элементами только с фиксированным набором свойств. Принцип непересечения грании требует, чтобы при картографировании не выделялись участки, относящиеся более чем к одному классу объектов. 


\section{2. Результаты исследований}

Базой для эколого-геоморфологического районирования БР по опасным геоморфологическим процессам послужила их классификация (табл. 1).

Общие принципы классификации опасных геоморфологических процессов разработаны нами в предыдущих исследованиях $[11,12]$. Однако в данном случае возникла необходимость ввести определенные корректировки: 1) в классификацию были включены только те геоморфологические процессы, которые распространены на территории исключительно БР и представляют реальную (а не гипотетическую) опасность для видов природопользования на этой территории; 2) ранги процессов определяются спецификой рельефа БР и особенностями его хозяйственного освоения, уровнем консолидированности и развитости территориально-производственных комплек- сов; 3) классификация не строго генетическая, в ней использованы также критерии, основанные на скорости, масштабах распространения и пространственной географической привязке опасных геоморфологических процессов; 4) пространственно-таксономическое соподчинение объектов соблюдено до ранга группы процессов.

Изложенные представления и объем исходной фактической информации легли в основу проведенного эколого-геоморфологического районирования БР по опасным геоморфологическим процессам (рисунок). Базовые виды хозяйственной деятельности и опасные процессы, региональные особенности их функционирования в наглядной форме представлены в табл. 2. В дальнейшем эти нечисловые вербальные показатели (параметры) могут быть интерпретированы в русле конкретных эколого-экономических задач.

\begin{tabular}{|c|c|c|c|}
\hline \multicolumn{4}{|c|}{ Опасные геоморфологические процессы } \\
\hline типы & классы & группы & отдельные процессы \\
\hline \multirow[t]{13}{*}{ Экзогенные } & \multirow{8}{*}{$\begin{array}{l}\text { Флювиальные } \\
\text { и комплексные } \\
\text { денудационные }\end{array}$} & Эрозионно-гравитационные & $\begin{array}{l}\text { Эрозия на склонах, формирование ложбин стока и деллей, } \\
\text { обвалы, осыпи, осовы }\end{array}$ \\
\hline & & Линейная эрозия & Донная и боковая эрозия рек \\
\hline & & \multirow[t]{4}{*}{ Площадная эрозия } & Плоскостной смыв, струйчатая эрозия, накопление делювия \\
\hline & & & Плоскостной смыв в сочетании с морозным выветриванием \\
\hline & & & Плоскостной смыв в сочетании с дефляцией \\
\hline & & & Плоскостной смыв в сочетании с курумообразованием \\
\hline & & $\begin{array}{l}\text { Аллювиальные } \\
\text { и пролювиальные }\end{array}$ & $\begin{array}{l}\text { Формирование террас в речных долинах и конусов выноса } \\
\text { в предгорных частях склонов }\end{array}$ \\
\hline & & Озерно-аллювиальные & $\begin{array}{l}\text { Формирование озерных террас, заболачивание озер с фор- } \\
\text { мированием сапропелевых толщ }\end{array}$ \\
\hline & \multirow[t]{3}{*}{ Гравитационные } & Гравитационные & Обвалы, осыпи \\
\hline & & Гидрогенно-гравитационные & Оползни, лавинообразование \\
\hline & & Гравитационно-дефляционные & $\begin{array}{l}\text { Формирование обвалов и осыпей при активном влиянии } \\
\text { выветривания и дефляции }\end{array}$ \\
\hline & \multirow[t]{2}{*}{ Эоловые } & Аккумулятивные & Формирование дюн, барханов, перевеянных песков \\
\hline & & Дефляционные & $\begin{array}{l}\text { Ветровая эрозия, формирование останцов обтачивания, } \\
\text { котловин выдувания, бедлендов }\end{array}$ \\
\hline
\end{tabular}


Продолжение таблицы 1

\begin{tabular}{|c|c|c|c|}
\hline \multicolumn{4}{|c|}{ Опасные геоморфологические процессы } \\
\hline \multirow[t]{14}{*}{ типы } & классы & группы & отдельные процессы \\
\hline & \multirow[t]{4}{*}{ Криогенные } & Поверхностного течения & $\begin{array}{l}\text { Солифлюкция, формирование оплывин и солифлюкционных } \\
\text { террас, крип, десерпция }\end{array}$ \\
\hline & & Термоэрозионные & $\begin{array}{l}\text { Термоэрозия, морозное пучение и формирование гидрола- } \\
\text { коллитов, мерзлотная трещиноватость }\end{array}$ \\
\hline & & Термокарстовые & $\begin{array}{l}\text { Термокарст, режеляция, формирование полигональных } \\
\text { грунтов, аласов }\end{array}$ \\
\hline & & Термогравитационные & $\begin{array}{l}\text { Курумообразование в сочетании с солифлюкцией, крипом, } \\
\text { обвалами, селями, лавинами }\end{array}$ \\
\hline & \multirow[t]{2}{*}{ Нивально-гляциальные } & Нивальные & Нивальные в сочетании с солифлюкцией, селями и обвалами \\
\hline & & Гляциальные & $\begin{array}{l}\text { Формирование экзарационных и аккумулятивных форм: } \\
\text { кары, цирки, троги, морены и др. }\end{array}$ \\
\hline & \multirow[t]{2}{*}{ Инфильтрационные } & Карстовые & Карстообразование поверхностное и подземное \\
\hline & & Суффозионные & Формирование суффозионных полостей и воронок \\
\hline & \multirow[t]{2}{*}{ Биогенно-хемогенные } & Элювиальные & Засоление, формирование травертинов, гейзеритов и т.п. \\
\hline & & Болотообразование & Заболачивание, торфообразование \\
\hline & \multirow[t]{3}{*}{ Береговые } & Абразионные & Абразия \\
\hline & & Аккумулятивные & Формирование дельт, кос, баров и береговых валов и т. п. \\
\hline & & Термические & Термоабразия и ледовая абразия \\
\hline \multirow[t]{3}{*}{ Эндогенные } & \multirow[t]{2}{*}{ Быстрые } & Сейсмогенные & $\begin{array}{l}\text { Формирование линейных деформаций грунтов, разрывы, } \\
\text { валы, уступы, просадки и т.п. в результате землетрясений }\end{array}$ \\
\hline & & Дизъюнктивные & $\begin{array}{l}\text { Формирование линейных форм рельефа в зонах активных } \\
\text { разломов: уступы, эскарпы, предгорные прогибы и т.п. }\end{array}$ \\
\hline & Медленные & Пликативные & Тектонический крип \\
\hline \multirow[t]{6}{*}{ Антропогенные } & \multirow{2}{*}{$\begin{array}{l}\text { Деструкция рельефа } \\
\text { при разработке полез- } \\
\text { ных ископаемых }\end{array}$} & Экспонированные & $\begin{array}{l}\text { Карьеры, искусственные котловины, штольни, терриконы, } \\
\text { россыпи и отвалы, хвостохранилища и т. п. }\end{array}$ \\
\hline & & Глубинные & $\begin{array}{l}\text { Шахты, штреки, буровые скважины, разрывы горных пород } \\
\text { при закачке отходов в глубокие горизонты земной коры, } \\
\text { просадочно-декомпрессионные полости и т.п. }\end{array}$ \\
\hline & \multirow[t]{2}{*}{$\begin{array}{l}\text { Деструкция рельефа } \\
\text { при распашке земель }\end{array}$} & Поверхностно-эрозионные & $\begin{array}{l}\text { Плоскостной смыв и дефляция, оврагообразование, форми- } \\
\text { рование бедлендов }\end{array}$ \\
\hline & & Поверхностно-аккумулятивные & Эоловая аккумуляция \\
\hline & \multirow[t]{2}{*}{$\begin{array}{l}\text { Прочие } \\
\text { техномобилизационные }\end{array}$} & Эрозионно-аккумулятивные & $\begin{array}{l}\text { Планировка и преобразование рельефа при строительстве } \\
\text { площадных и линейных объектов }\end{array}$ \\
\hline & & $\begin{array}{l}\text { Релаксационно- } \\
\text { компенсационные }\end{array}$ & Наведенная сейсмичность \\
\hline
\end{tabular}


Региональная безопасность Проблемы анализа риска, том 15, 2018, № 6

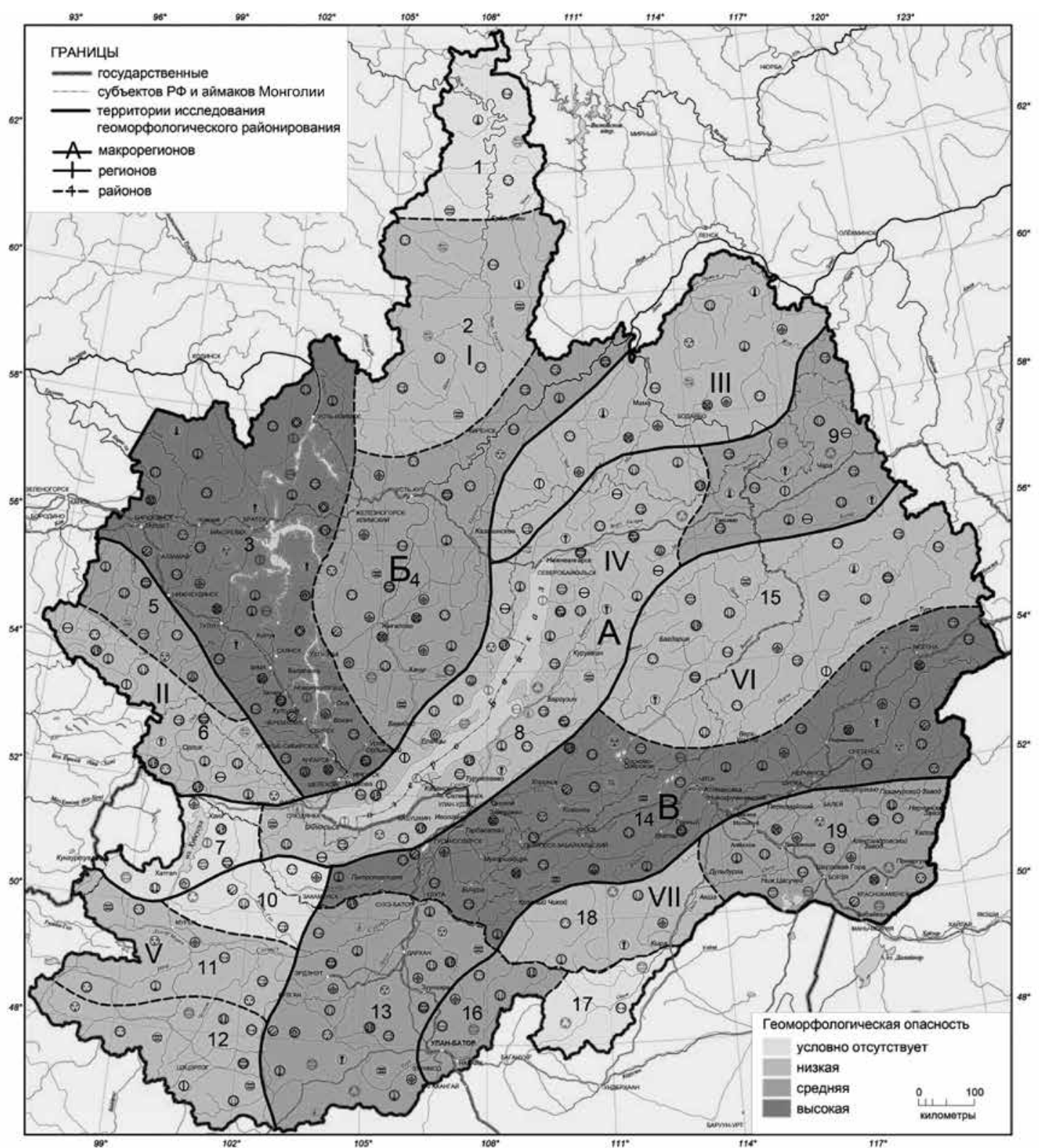

ORACHAE TEOMOPФONOTИUECMUE NPOLECCD.
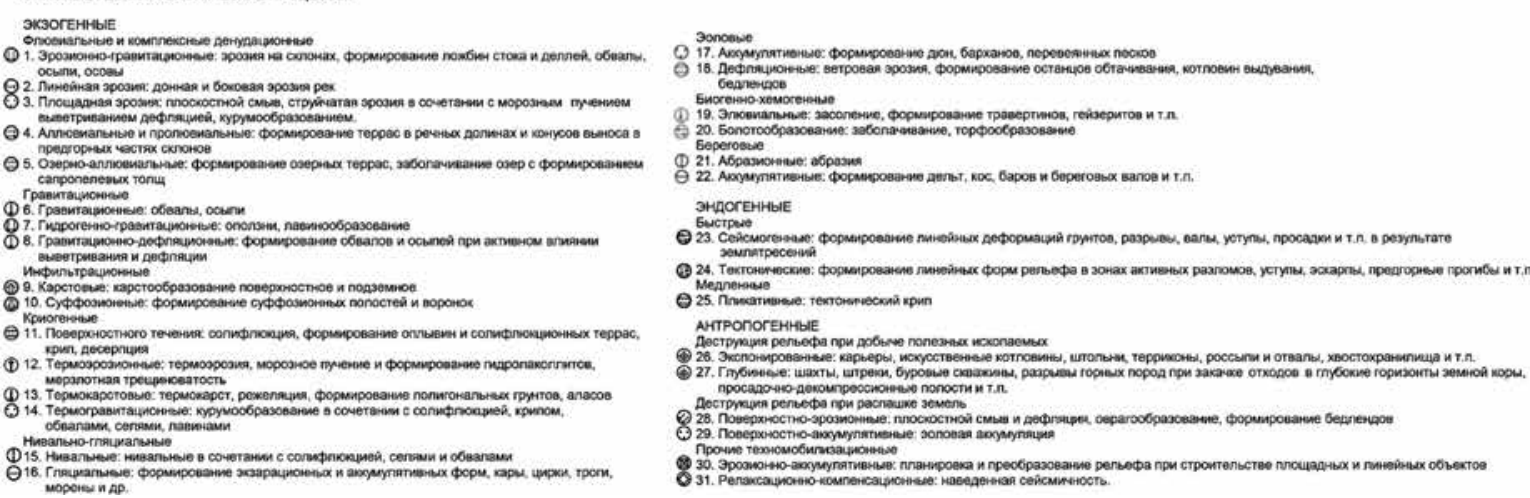

Рисунок. Карта эколого-геоморфологического районирования Байкальского региона по опасным геоморфологическим процессам. Номера и наименования макрорегионов, регионов и районов см. в табл. 2 
Главные виды хозяйственной деятельности в единицах районирования БР

\begin{tabular}{|c|c|c|c|c|}
\hline \multicolumn{3}{|c|}{ Единицы районирования } & \multicolumn{2}{|l|}{ Виды хозяйственной деятельности } \\
\hline макрорегион & регион & район & существующие & планируемые \\
\hline \multirow[t]{7}{*}{$\begin{array}{l}\text { А. Предбай- } \\
\text { кальский }\end{array}$} & \multirow[t]{4}{*}{$\begin{array}{l}\text { І. Средне- } \\
\text { сибирский }\end{array}$} & 1. Нижнетунгусский & $\begin{array}{l}\text { Охотничий и рыбный промысел, лесо- } \\
\text { заготовка, традиционные промыслы, } \\
\text { туризм }\end{array}$ & $\begin{array}{l}\text { Лесозаготовка, транспорт, туризм } \\
\text { и рекреация }\end{array}$ \\
\hline & & 2. Непа-Тунгусский & $\begin{array}{l}\text { Охотничий и рыбный промысел, лесное } \\
\text { хозяйство, традиционные промыслы, } \\
\text { оленеводство }\end{array}$ & $\begin{array}{l}\text { Лесопереработка, газонефтедобы- } \\
\text { ча, туризм и рекреация }\end{array}$ \\
\hline & & 3. Ангарский & $\begin{array}{l}\text { Лесозаготовка, гидроэнергетика, де- } \\
\text { ревообработка, цветная металлургия, хи- } \\
\text { мическая, машиностроение, нефтепере- } \\
\text { рабатывающая, горнорудная, угольная, } \\
\text { скотоводство, земледелие, транспорт }\end{array}$ & $\begin{array}{l}\text { Разработка месторождений нефти } \\
\text { и газа, гидроэнергетика, нефтега- } \\
\text { зоперерабатывающая, трубопро- } \\
\text { водный транспорт }\end{array}$ \\
\hline & & 4. Ленский & $\begin{array}{l}\text { Геологоразведка, горнорудная, газо- } \\
\text { нефтепромысловая, воднотранспортная, } \\
\text { животноводство, охотничий и рыбный } \\
\text { промысел, оленеводство }\end{array}$ & $\begin{array}{l}\text { Высокоперспективная нефтегазо- } \\
\text { добывающая, горнорудная, горно- } \\
\text { химическая, транспорт }\end{array}$ \\
\hline & \multirow[t]{2}{*}{ II. Саянский } & 5. Предсаянский & $\begin{array}{l}\text { Молочно-мясное скотоводство, овце- } \\
\text { водство, земледелие, приусадебное } \\
\text { хозяйство }\end{array}$ & $\begin{array}{l}\text { Горнодобывающая, сельское } \\
\text { хозяйство, туризм }\end{array}$ \\
\hline & & 6. Горно-Саянский & $\begin{array}{l}\text { Горнодобывающая и горно-перерабаты- } \\
\text { вающая, животноводство, туристско-ре- } \\
\text { креационная }\end{array}$ & $\begin{array}{l}\text { Горно-перерабатывающая, сель- } \\
\text { ское хозяйство }\end{array}$ \\
\hline & $\begin{array}{l}\text { III. Мама- } \\
\text { Патомский }\end{array}$ & - & $\begin{array}{l}\text { Горнодобывающая и горно-перераба- } \\
\text { тывающая, в т.ч. золоторудная, лесные } \\
\text { и традиционные промыслы, олене- } \\
\text { водство, охото-промысловая, водный } \\
\text { и автомобильный транспорт }\end{array}$ & $\begin{array}{l}\text { Геологоразведка, транспорт, ско- } \\
\text { товодство, земледелие, туристско- } \\
\text { рекреационная, горнодобывающая }\end{array}$ \\
\hline \multirow[t]{3}{*}{$\begin{array}{l}\text { Б. Центрально- } \\
\text { Байкальский }\end{array}$} & \multirow[t]{3}{*}{$\begin{array}{l}\text { IV. Прибайкаль- } \\
\text { ский }\end{array}$} & 7. Прихубсугульский & $\begin{array}{l}\text { Мясо-молочное скотоводство, овцевод- } \\
\text { ство, пищевая, строительные материалы, } \\
\text { энергетика }\end{array}$ & $\begin{array}{l}\text { Туризм, рекреация, пищевая, сель- } \\
\text { ское хозяйство, энергетика }\end{array}$ \\
\hline & & 8. Байкальский & $\begin{array}{l}\text { Охото-рыбо-промысловая, рекреация, } \\
\text { туризм, лесное хозяйство, скотоводство, } \\
\text { земледелие }\end{array}$ & $\begin{array}{l}\text { Рекреация, туризм, сельское } \\
\text { хозяйство, транспорт }\end{array}$ \\
\hline & & 9. Становой & $\begin{array}{l}\text { Лесные и традиционные промыслы, оле- } \\
\text { неводство, небольшие очаги горнодобы- } \\
\text { вающей промышленности }\end{array}$ & $\begin{array}{l}\text { Горнорудная, ж/д и автомобильный } \\
\text { транспорт }\end{array}$ \\
\hline \multirow[t]{3}{*}{$\begin{array}{l}\text { В. Забайкаль- } \\
\text { ский }\end{array}$} & \multirow[t]{3}{*}{$\begin{array}{l}\text { V. Западно- } \\
\text { Монгольский }\end{array}$} & 10. Джидинский & $\begin{array}{l}\text { Овцеводство, кожевенная, лесозаготови- } \\
\text { тельная, оленеводство, горнодобываю- } \\
\text { щая (вольфрам) }\end{array}$ & $\begin{array}{l}\text { Лесоперерабатывающая, легкая, } \\
\text { транспорт }\end{array}$ \\
\hline & & $\begin{array}{l}\text { 11. Верхне- } \\
\text { Селенгинский }\end{array}$ & $\begin{array}{l}\text { Скотоводство, горнодобывающая (уголь, } \\
\text { уран, свинец), легкая, лесозаготовка, } \\
\text { деревообрабатывающая, черная метал- } \\
\text { лургия, металлообработка }\end{array}$ & $\begin{array}{l}\text { Лесозаготовка и лесопереработка, } \\
\text { горнодобывающая, металлообра- } \\
\text { ботка, транспорт }\end{array}$ \\
\hline & & $\begin{array}{l}\text { 12. Северо- } \\
\text { Хангайский }\end{array}$ & $\begin{array}{l}\text { Животноводство, легкая, пищевая, ле- } \\
\text { созаготовка, строительных материалов, } \\
\text { энергетика }\end{array}$ & $\begin{array}{l}\text { Пищевая, транспорт, лесоперера- } \\
\text { батывающая, энергетика }\end{array}$ \\
\hline
\end{tabular}


Продолжение таблиць 2

\begin{tabular}{|c|c|c|c|c|}
\hline \multicolumn{3}{|c|}{ Единицы районирования } & \multicolumn{2}{|l|}{ Виды хозяйственной деятельности } \\
\hline макрорегион & регион & район & существующие & планируемые \\
\hline & \multirow[t]{3}{*}{$\begin{array}{l}\text { VI. Центрально- } \\
\text { Забайкальский }\end{array}$} & 13. Орхонский & $\begin{array}{l}\text { Мясо-молочное скотоводство, овцевод- } \\
\text { ство, земледелие, горнодобывающая } \\
\text { (уголь, уран, медь, железо, золото), лес- } \\
\text { ная, деревообработка, легкая, топлив- } \\
\text { ная, цветная металлургия }\end{array}$ & $\begin{array}{l}\text { Животноводство, лесохимическая, } \\
\text { энергетическая, горно-перера- } \\
\text { батывающая, туризм, транспорт, } \\
\text { нефтегазовая }\end{array}$ \\
\hline & & $\begin{array}{l}\text { 14. Хилок- } \\
\text { Шилкинский }\end{array}$ & $\begin{array}{l}\text { Лесное и сельское хозяйство, обраба- } \\
\text { тывающая промышленность, машино- } \\
\text { строение, горнорудная, пригородное } \\
\text { хозяйство, рекреация }\end{array}$ & $\begin{array}{l}\text { Горнодобывающая, лесоперера- } \\
\text { батывающая, лесохимическая, } \\
\text { рекреация }\end{array}$ \\
\hline & & 15. Витимский & $\begin{array}{l}\text { Лесные промыслы, очаги горнорудной } \\
\text { и деревообрабатывающей промышлен- } \\
\text { ности }\end{array}$ & $\begin{array}{l}\text { Долинное земледелие, животно- } \\
\text { водство }\end{array}$ \\
\hline & \multirow[t]{4}{*}{$\begin{array}{l}\text { VII. Восточно- } \\
\text { Забайкальский }\end{array}$} & 16. Улан-Баторский & $\begin{array}{l}\text { Легкая, пищевая, животноводство, энер- } \\
\text { гетическая, горнодобывающая (бурый } \\
\text { уголь, стройматериалы), перерабатываю- } \\
\text { щая, машиностроение }\end{array}$ & $\begin{array}{l}\text { Легкая, пищевая, транспорт, лесо- } \\
\text { перерабатывающая, энергетиче- } \\
\text { ская, горнодобывающая }\end{array}$ \\
\hline & & $\begin{array}{l}\text { 17. Верхне- } \\
\text { Ононский }\end{array}$ & $\begin{array}{l}\text { Животноводство, лесная, пищевая, } \\
\text { горнорудная, топливная, традиционные } \\
\text { промыслы }\end{array}$ & $\begin{array}{l}\text { Туризм и рекреация, транспорт, } \\
\text { энергетика }\end{array}$ \\
\hline & & $\begin{array}{l}\text { 18. Чикой- } \\
\text { Ингодинский }\end{array}$ & $\begin{array}{l}\text { Туризм, земледелие, традиционные про- } \\
\text { мыслы, скотоводство, лесное хозяйство }\end{array}$ & $\begin{array}{l}\text { Туризм, рекреация, лесное хозяй- } \\
\text { ство }\end{array}$ \\
\hline & & 19. Онон-Аргунский & $\begin{array}{l}\text { Овцеводство, мясо-молочное скотовод- } \\
\text { ство, очаги горнодобывающей промыш- } \\
\text { ленности }\end{array}$ & $\begin{array}{l}\text { Сельское хозяйство, горно-пере- } \\
\text { рабатывающая }\end{array}$ \\
\hline
\end{tabular}

Важно отметить, что трансграничный аспект в деле охраны окружающей среды БР и защиты от опасных природных процессов определяется как опытом многолетнего сотрудничества РФ (ранее СССР) и РМ в этом аспекте, так и протяженной государственной границей между странами. Последнее обстоятельство особенно важно в процессе проведения пространственного географического анализа и картографирования опасных геоморфологических процессов. Между субъектами РФ и РМ проходит государственная граница, протяженность которой с Республикой Бурятия составляет 1213,6 км и с Забайкальским краем 863 км. Со стороны Республики Бурятия в приграничной полосе расположены следующие ее административные районы: Окинский, Тункинский, Закаменский, Джидинский, Кяхтинский. Площадь приграничной полосы, на которой проживает около

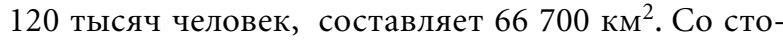
роны Забайкальского края расположены административные районы: Красночикойский, Кыринский, Акшинский, Ононский, Борзинский. Площадь при-

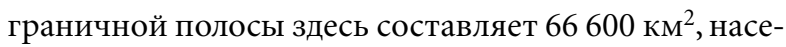
ление - 116 тысяч человек. Таким образом, общая протяженность границы на сопредельной территории составляет 2076,6 км, а общая площадь приграничной полосы - 133300 км², всего здесь проживает около 236 тысяч человек. Со стороны Республики Монголия в приграничной полосе расположены аймаки: Хубсугульский, Булганский, Селенгинский, Хэнтийский, Восточный. Площадь приграничной полосы составляет 394400 км² $^{2}$ население - более 430 тысяч человек [16].

Видим, что даже непосредственная трансграничная полоса между РФ и РМ, которая является только частью всего БР, имеет внушительные параметры: 
протяженность - 2076,6 км, площадь - 527700 км², население - более 656 тысяч человек. Если же учитывать весь БР, то площадь и население вырастают практически на порядок. Но есть и другое важное обстоятельство: часть БР - самый восток Забайкальского края - не входит в состав бассейна оз. Байкал, а принадлежит бассейну р. Амур. И здесь граница БР на значительном протяжении проходит между РФ и Китайской Народной Республикой (КНР). Со стороны КНР трансграничная полоса значительна по площади и очень густо населена. В хозяйственном отношении здесь в последнее время наблюдается настоящий экономический бум. Более того, вся территория БР является транзитной между РФ и КНР, другими странами Юго-Восточной Азии, да и всего Азиатско-Тихоокеанского сектора. Через него проходят мощные международные финансовые, материальные и информационные потоки. Экономика региона активно развивается в последние 15-20 лет, что неминуемо влечет за собой постановку и решение острых задач обеспечения безопасности хозяйства и окружающей природной среды.

\section{Заключение}

В результате проведенного эколого-геоморфологического районирования БР выделено 3 крупных макрорегиона - Предбайкальский, Центрально-Байкальский, Забайкальский.

Предбайкальский регион включает большую часть Иркутской области и небольшие участки Республики Бурятия на крайнем юго-западе и северовостоке. Практически весь макрорегион не является частью бассейна оз. Байкал, но высокий уровень хозяйственного развития здесь оказывает существенное влияние на окружающую природную среду, приводит к активизации и возникновению многих опасных геоморфологических процессов.

Центрально-Байкальский макрорегион охватывает часть Иркутской области, значительную часть Республики Бурятия, а на крайнем северо-востоке и небольшой фрагмент Забайкальского края. Дополнительно на крайнем западе он включает и территорию Республики Монголия, т.е. его уже можно определенно считать трансграничным. Почти вся территория макрорегиона входит в состав бассейна оз. Байкал. Она имеет наиболее строгие законодательно утвержденные ограничения на ведение хо- зяйственной деятельности, т.к. входит в Центральную экологическую зону БПТ с наивысшим уровнем охраны природы.

Забайкальский макрорегион уже в полной мере является трансграничным, поскольку включает часть Республики Бурятия, большую часть Забайкальского края, а также примерно на 40\% площадь РМ. Макрорегион на 60\% принадлежит бассейну оз. Байкал (преимущественно на территории РМ) и примерно по 20\% - бассейнам рек Лена и Амур.

По эколого-геоморфологическим регионам ситуация следующая.

Большую часть Предбайкальского макрорегиона занимает Среднесибирский регион (около 60\% площади), а примерно по 20\% приходится на Саянский и Байкало-Патомский регионы. Это связано, прежде всего, со спецификой опасных геоморфологических процессов, которые в первом случае протекают в условиях платформенного спокойного геодинамического режима (Сибирский кратон), а в двух других - в условиях активной геодинамики горно-складчатых областей. Также Среднесибирский регион является наиболее экономически развитым в БР, с широким спектром хозяйственных отраслей (Иркутская область). Два других региона отличаются слабо развитой экономикой со скудной хозяйственной структурой, представленной главным образом горнодобывающими отраслями.

Центрально-Байкальский макрорегион целиком состоит из Прибайкальского региона. Такой дуализм в районировании связан со следующими причинами. С одной стороны, эта территория настолько значима как с экологической, так и с экономической точки зрения, что заслуживает в принятом масштабе исследований самостоятельной таксономической единицы на уровне макрорегиона. С другой стороны, главным консолидирующим фактором ее единства является оз. Байкал и законодательно утвержденная в России в его ближайшем окружении Центральная экологическая зона БПТ, для которой установлены самые строгие экологические ограничения на ведение хозяйственной деятельности. Это в полной мере относится и к Прихубсугульскому району на территории Республики Монголия.

Большую часть Забайкальского макрорегиона занимает Центрально-Забайкальский регион (около 
50\% территории). Примерно 20\% приходится на Западно-Монгольский регион и $30 \%$ - на Восточно-Забайкальский. Специфика опасных геоморфологических процессов первого из них заключается в том, что он является переходной зоной между геодинамически активной Байкальской рифтовой зоной и относительно пассивными микроплитами Забайкалья: для Восточно-Забайкальского региона - Амурской литосферной плиты, для ЗападноМонгольского региона - Хангайского микроблока, который тем не менее заметно активизирован на современном геотектоническом этапе. Отличаются эти регионы и спецификой хозяйственной деятельности. Для Западно-Монгольского региона - это в основном сельское хозяйство и лесозаготовка, для Восточно-Забайкальского района к этому добавляются туризм и отчасти горнодобывающая отрасль, а для Центрально-Забайкальского района характерен широкий спектр и относительно высокий уровень развития экономики.

Еще большая специфика опасных геоморфологических процессов и находящихся под их воздействием отраслей экономики характерна для эколого-геоморфологических районов. Для подробного рассмотрения этих вопросов необходимо обратиться к рисунку и табл. 2.

Таким образом, районирование БР по опасным геоморфологическим процессам отвечает нуждам внутри- и межгосударственной политики Российской Федерации и Республики Монголия, их важным трансграничным и геополитическим интересам. Выделенные на карте пространственные единицы районирования не являются изолированными от всего народно-хозяйственного комплекса РФ и РМ, а представляют собой органичную его часть, тесно связанную (интегрированную) с другими территориальнопроизводственными структурами. Границы выделенных на карте объектов (районов) законодательно не закреплены, и тем не менее они сосредоточивают в себе значительную часть информации по геоэкологическим проблемам всего БР, играют важную роль в регулировании и координации развития и совершенствования производительных сил и производственных отношений в РФ и РМ.

Прошедший в сентябре 2017 г. форум стран БРИКС показал, что сотрудничество со всеми странами Азиатско-Тихоокеанского сектора сегодня во многом определяет вектор общемировой экономической, социальной и экологической политики. Развитие восточных регионов РФ в тесном сотрудничестве с РМ, КНР, Японией и др. позволит странам органично влиться в мировую систему торговых и геополитических отношений, а защита хозяйственной деятельности и окружающей природной среды будет всецело зависеть от квалифицированной оценки опасных природных процессов, источников их возникновения и проистекающих из них острых эколого-экономических ситуаций. Поэтому и стратегические планы РФ и РМ должны быть строго взаимоувязаны и базироваться на обеспечении экологической безопасности всего БР, на обеспечении его защиты от стихийных бедствий и катастроф.

Субъекты РФ, входящие в Байкальский регион, - Иркутская область, Республика Бурятия, Забайкальский край - испытали значительные экономические потрясения в последние годы в результате введения странами Запада санкций в отношении РФ. Внешнеторговый оборот этих регионов изменялся с 2013 по 2016 г. следующим образом: Иркутская область - с 9,33 до 6,49 млрд долл. в год; Республика Бурятия - c 1,203 до 1,020 млрд долл. в год; Забайкальский край - c 0,830 до 0,620 млрд долл. в год [7]. Это стимулирует развитие экономики данных регионов в ближайшем будущем, что естественным образом будет сказываться на усилении техногенного прессинга на природные системы и активизации опасных природных процессов.

Районирование БР по опасным геоморфологическим процессам в круге задач, решаемых МЧС РФ и ГУЧС РМ, будет способствовать внедрению особой политики этих стран по прогнозу, предупреждению и ликвидации ЧС природного и природно-техногенного характера. В устойчивом административно-государственном механизме защита от опасных процессов происходит упорядоченно и обоснованно, на строгой законодательной основе, поэтому структурам МЧС РФ и ГУЧС РМ совместно с управленческим аппаратом необходимо будет решать ряд многокритериальных задач. А в условиях рыночных отношений и высокой конкуренции на мировом рынке, усиления децентрализации и многополярности мировой экономической системы новые черты приобретает территориальная комплексность хо- 
зяйства крупных трансграничных регионов. Ее показателем становится четкое соответствие хозяйства региона его природным и социально-экономическим условиям, рациональное сочетание хозяйственных отраслей на базе ведущих специализирующих производств и их территориальной концентрации, сходство отраслевой структуры входящих в регион районов. Важным требованием являются также эффективно функционирующая система защиты населения и хозяйства от стихийных бедствий и катастроф, профилактика ЧС.

Составленная нами карта эколого-геоморфологического районирования БР и подобные ей картографические произведения, разработанные на основе как предлагаемого подхода, так и других возможных методов построения и анализа, могут стать пространственным базисом проведения специализированных превентивных мероприятий в рамках предупреждения и ликвидации ЧС природного и природно-техногенного характера на территории БР. В территориальных подразделениях МЧС РФ и ГУЧС РМ, которые в своей деятельности руководствуются нормативными документами, такие карты могут быть адаптированы под существующую номенклатурную основу, позволят эффективно использовать пространственный географический анализ в вопросах мониторинга опасных природных процессов, совершенствовать государственную систему прогноза стихийных бедствий и катастроф.

Карты опасных природных процессов и районирования территорий на их основе играют большую роль в информировании гражданского населения и руководителей разного звена о прогнозируемых и возникающих ЧС природного и природно-техногенного характера. Они могут быть использованы территориальными органами МЧС Иркутской области, Республики Бурятия и Забайкальского края, а также аймаков Республики Монголия при разработке мер по обеспечению безопасности населения, хозяйственных объектов и территорий, приемов и способов их защиты, при осуществлении пропаганды в области ГО и ЧС.

\section{Литература [References]}

1. Баженова О.И., Мартьянова Г.Н. Формирование экстремальных морфоклиматических ситуаций на юге Сибири // География и природные ресурсы, 2004.
№4. C. 87-94. [Bazhenova O.I., Mart'yanova G.N. A formation of extremal morphoclimatic situations in South Siberia // Geography and Natural Resources, 2004. № 4. Р. 87-94.]

2. Винокуров Ю.И., Цимбалей Ю.М., Красноярова Б.А. Физико-географическое районирование Сибири как основа разработки региональных систем природопользования // Ползуновский вестник, 2005. №4. Ч. 2. С. 3-13. [Vinokurov Yu.I., Cimbalej Yu.M., Krasnoyarova B.A. Physical-geographical regionalization of Siberia as a basis to creation of regional systems of natureuse // Polzunov’s Bulletin, 2005. № 4. Chapter. 2. P. 3-13.]

3. Елисеева И.И., Рукавишников В.О. Группировка, корреляция, распознавание образов. М.: Статистика, 1977. 144 c. [Eliseeva I.I., Rukavishnikov V.O. Grouping, correlation, pattern recognition. M.: Statistika, 1977. 144 p.]

4. Енюков И.С. Методы, алгоритмы, программы многомерного статистического анализа. М.: Финансы и статистика, 1986. 232 c. [Enyukov I.S. Methods, algorithms, multidimensional statistical analysis programs. Moscow: Finance and statistics Press, 1986. 232 p.]

5. Ивченко Б.П., Мартыщенко Л.А. Информационная экология. СПб.: Нордмед-Издат, 1998. 208 с. [Ivchenko B.P., Martyshchenko L.A. Information ecology. St. Petersburg: Nordmed-Izdat, 1998. 208 p.]

6. Карта районирования территории России по степени экстремальности развития эколого-геоморфологических ситуаций. Масштаб 1:9000000. М.: ООО «ДиЭмБи», 2006. [The map of regionalization of territory of Russia along the degree of exremality of ecological-geomorphological situations. Scale 1:9000 000]. M.: DMB Press, 2006.]

7. Ковалева Г.Д., Костин А.В. Оценка влияния внешних воздействий на торговлю регионов Сибирского федерального округа // Регион: экономика и социология, 2017. Том 96. № 4. С. 200-219. [Kovaleva G.D., Kostin A.V. Estimation of influence of external factors on trade of regions of the Siberian federal district] // Region: Economics and Sociology, 2017. Vol. 96. № 4. P. 200-219.]

8. Корытный Л.М., Воробьева И.Б., Коновалова Т.И., Кузьмин С.Б., Шеховцов А.И. Районирование и ранжирование территории Иркутской области по природной и техногенной опасности // Экологический риск / Под ред. А.Н. Антипова. Иркутск: ИГ СО PAH. 2001. C. 114-117. [Korytnyj L.M., Vorob'eva I.B., Konovalova T.I., Kuzmin S.B., Shekhovcov A.I. Regionalization and ranging of Irkutsk Oblast along the natural and 
technical disasters // Ecological risk / Ed. A.N. Antipov. Irkutsk: IG SB RAS Press. 2001. P. 114-117.]

9. Копылов И.С., Лунев Б.С., Наумова О.Б., Маклашин А.В. Геоморфологические ландшафты как основа геоэкологического районирования // Фундаментальные исследования, 2014. №11-10. C. 2196-2201. [Kopylov I.S., Lunev B.S., Naumova O.B., Maklashin A.V. Geomorphological landscapes as a basis for geoecological zoning] // Fundamental Reseraches, 2014. № 11-10. Р. 2196-2201.]

10. Кочуров Б.И. Экодиагностика и сбалансированное развитие. Москва - Смоленск: Маджента, 2003. 384 с. [Kochurov B.I.Ecodiagnosis and sustainable development. Moscow — Smolensk: Madzhenta Press, 2003.384 s.]

11. Кузьмин С.Б. Классификация опасных морфогенетических процессов Иркутской области // Известия РГО, 2006. Т. 138. Вып. 3. С. 64-70. [Kuzmin S.B. Classification of hazardous morphogenetic processes in the Irkutsk Oblast // News of the Russian Geographical Society, 2006. Vol. 138. № 3. P. 64-70.]

12. Кузьмин С.Б., Шаманова С.И. Районирование Иркутской области по опасным геоморфологическим процессам и их синергетическое моделирование // Известия РГО, 2014. Т. 146. № 2. С. 9-21. [Kuzmin S. B., Shamanova S.I.Zoning of the Irkutsk Oblast on hazardous geomorphological processes and their synergetic modeling // News of the Russian Geographical Society, 2014. Vol. 146. № 2. P. 9-21.]

13. Кузьмин С.Б., Лопаткин Д.А., Шаманова С.И., Кичигина Н.В. Опасные природные процессы // География Сибири в начале XXI века: В 6 т. Т. 2. Природа. Отв. ред. В.М. Плюснин. Новосибирск: ГЕО, 2015. С. 274-330. [Kuzmin S.B., Lopatkin D.A., Shamanova S.I., Kichigina N.V. Natural disasters // Geography of Siberia in XXI beginning. Vol. 2. Nature. Ed. V.M. Plyusnin. Novosibirsk: GEO Press, 2015. P. 274-330.]

14. Кузьмин С.Б., Лопаткин Д.А. Картографирование опасных геоморфологических процессов Сибири // Геодезия и картография, 2016. №4. С. 28-39. [Kuzmin S.B., Lopatkin D.A. Mapping of hazardous geomorphological processes in Siberia // Geodesy and Cartography, 2016. № 4. P. 28-39.]

15. Лапердин В.К., Качура Р.А. Геодинамика опасных процессов в зонах природно-техногенных комплексов Восточной Сибири // Иркутск: Институт земной коры CO PAH. 2010.312 c. [Laperdin V.K., Kachura R.A. Geodynamics of hazardous processes in zones of natural- technical complexes // Irkutsk: Institute of the Earth's Crust SB RAS Press, 2010.312 p.]

16. Менчук В.В. Трансграничное взаимодействие структур МЧС России и структур Государственного агентства по ЧС Монголии при предупреждении и ликвидации приграничных чрезвычайных ситуаций // Записки Забайкальского отделения Русского географического общества. Вып. 135: Географические исследования пригранично-периферийных районов в рыночных условиях, 2016. C. 230-237. [Menchuk V.V. Cross-border interaction between the structures of the Ministry of Emergency Situations of Russia and the structures of the State Agency for Emergency Situations of Mongolia in the Prevention and Elimination of Border Emergency Situations // Notes of the Transbaikal Branch of the Russian Geographical Society 135: Geographical Investigations of Border-Peripheral Regions in Market Conditions, 2016. Р. 230-237.]

17. Природно-антропогенные процессы и экологический риск / Под ред. С.М. Малхазовой и Р.С. Чалова. М.: Городец, 2004.616 c. [Natural-technical processes and ecological risk] / Ed. S.M. Malkhazova and R.S. Chalov. M.: Gorodec Press, 2004. 616 p.]

18. Природные опасности России. Т. 3. Экзогенные геологические опасности / Под ред. В.И.Осипова, С.К. Шойгу. М.: КРУК, 2002. 345 с. [Natural disasters of Russia. Vol. 3. Exogenic geological disasters / Ed. V.I. Osipov and S.K. Shoygu. M.: KRUK, 2002.345 p.]

19. Радаев Н.Н. Обоснование уровней рисков в чрезвычайных ситуациях природного и техногенного характера // Известия РАН. Серия географическая, 2003. №5. C. 74-86. [Radaev N.N. Rationale of risk degree in emergencies of natural and technical character // Proceedings of the Russian Academy of Sciences. Geographic series, 2003. № 5. Р. 74-86.]

20. Рельеф среды жизни человека / Под ред. Э.А. Лихачевой и Д.А. Тимофеева. М.: Медиа-ПРЕСС. 2002. 640 c. [Topography of human being environment / Ed. E.A. Likhacheva and D.A. Timofeev. M.: Media-PRESS. 2002. 640 p.]

21. Тикунов В.С. Классификации в географии. Смоленск: Изд-во Смоленского госуни-та, 1997. 367 с. [Tikunov B.C. Classification in geography. Smolensk: Smolens University Press, 1997. 367 p.]

22. Тржцинский Ю.Б., Козырева Е.А., Мазаева О.А., Хак В.А. Современная геодинамика юга Сибирского региона. Иркутск: Институт земной коры CO PAH, 2007. 155 c. [Trzhcinsky Yu.B., Kozyreva E.A., 
Mazaeva O.A., Khak V.A. Modern geodynamics of the south of the Siberian region. Irkutsk: Institute of the Earth's Crust SB RAS Press, 2007. 155 p.]

23. Умывакин В.М. Интегральная эколого-хозяйственная оценка и управление земельными ресурсами в регионе. Воронеж: Изд-во Воронежского гос. пед. унта, 2002. 178 c. [Umyvakin V.M. Integral eco-economic assessment and land management in the region. Voronezh: Voronezh Pedagogic University Press, 2002. 178 p.]

24. Bruins R.J.F., Heberling M.T. Economic and Ecological Risk Assessment. Application to Watershed Management. Boca Raton: CRC Press. 2005. 446 p.

25. Enz R., Karl K., Mehlhorn J. Natural catastrophes and man-made disasters // Sigma. 2008. № 2. P. 1-48.

26. Lobo D., Lozano Z., Delgado F. Water erosion risk assessment and impact on productivity of a Venezuelan soil // Catena. 2005. Vol. 64. №2-3. P. 297-306.

27. McGuire B., Mason I., Kilburn C. Natural hazards and environmental change. London: Arnold Press. 2002. 187 p.

28. Pignatelli C., Plantone M., Romaniello L. Geomorphological risk assessment along Apulian coast // Quaternary
Physical and Dynamic Geography. 2006. Vol. 29. № 1. P. 93-106.

29. Posner R.A. Catastrophe: risk and response. Oxford: Oxford University Press, 2004. 332 p.

30. Srivastava R., Laurian L. Natural hazard mitigation in local comprehensive plans. A case of flood, wildfire and drought planning in Arizona // Disaster Prevention \& Managing. 2006. Vol. 15. № 3. P. 461-483.

\section{Сведения об авторе}

Кузьмин Сергей Борисович: доктор географических наук, ведущий научный сотрудник Института географии им. В.Б. Сочавы СО РАН

Количество публикаций: 205, в т.ч. монографий - 11

Область научных интересов: геоморфология, геоэкология, ландшафтоведение, рациональное природопользование, ГИС-картографирование

Контактная информация:

Адрес: 664033, г. Иркутск, ул. Улан-Баторская, д. 1

Тел.: +7 (914) 872-04-56

E-mail: kuzmin@irigs.irk.ru 